\title{
Cerebral Strokes Associated with Pregnancy and the Puerperium
}

\author{
JAMES N. CROSS,* F.R.C.S.ED. ; P. OSCAR CASTRO, † M.D. ; W. BRYAN JENNETT, $\ddagger$ M.D., F.R.C.S.
}

Erit. med.F., 1908, 3, 214-218

\begin{abstract}
Summary : Thirty-one cases of ischaemic cerebral stroke occurring in association with childbirth were fully investigated. The pathological basis of non-haemorrhagic carotid territory strokes in pregnant or puerperal women proved to be similar to that in non-pregnant women of the same age group. Over $70 \%$ were due to occlusive cerebral arterial disease or ischaemic lesions unrelated to thrombosis of the intracranial venous system. Comparisons are made with some other reported series in which only a minority of the patients were investigated by angiography, but in which intracranial venous occlusion was assumed to be the primary lesion. It seems likely that many of these patients may also have suffered arterial rather than venous lesions.
\end{abstract}

\section{Introduction}

Hemiplegia is an unusual hazard of child-bearing and is commonly ascribed to cerebral thrombophlebitis. In most of the reported cases the diagnosis has been presumptive because very few survivors have had angiograms, or the fatal cases necropsies. In a series of 31 patients who were fully investigated occlusion of a major artery was found in 17 cases and cerebral infarction in 25 . Though most of the published reports claim that the cortical veins or the venous sinuses are the site of the primary pathology, review of details of the reported cases suggests that several may have had arterial lesions.

This paper explores the incidence and nature of non-haemorrhasic hemiplegic strokes associated with pregnancy and the puerperium; and it challenges the assertion that cerebral venous thrombosis is the usual pathological basis.

\section{Patients and Methods}

During the 10-year period 1956-65 a total of 523 patients were discharged from the neurosurgical unit at Killearn Hospital with the diagnosis of ischaemic carotid territory stroke. Tweniy-three of the whole series were women who were pregnant or puerperal at the time of their stroke. During the same period 27 other pregnant or puerperal women were referred for investigation-11 had spontaneous intracranial haemorrhage, 9 tumours of the central nervous system, and 7 a variety of intracranial conditions, including epilepsy and cerebral abscess. Thus non-haemorrhagic carotid territory stroke proved to be the commonest single cause for referral of a pregnant or puerperal woman for neurosurgical investigation. In the succeeding two years eight further women have been investigated for hemiplegic strokes in association with child-bearing, making 31 such cases available for analysis.

This neurosurgical unit serves the whole of the Western Region of Scotland with a population of some three million. Orly very limited facilities for carotid angiography were available elsewhere in Glasgow during the years 1956 to 1967, and it is likely that most cases of major carotid strokes requiring angiography would have been referred to the unit. In order

- Lectarer in Neurosurgery.

t Registrar in Neurosurgery.

Professor of Neurosurgery.
Institurte of Neurological Sciences, Glasgow to assess the proportion of such patients actually referred for investigation a survey of admissions to two of the larger maternity hospitals in the Western Region was carried out and the records concerning maternal mortality in Glasgow were also inspected; these sources yielded only three cases not already known to us. It was concluded, therefore, that most patients with major carotid territory strokes associated with child-bearing during the years 1956 to 1967 had been investigated here. Carotid territory ischaemia is defined as any sudden dysfunction involving the cerebral hemisphere; this includes weakness of a limb or the face, dysphasia, hemianopia, or cortical sensory disturbance, but excludes loss of consciousness or epilepsy if these presented without evidence of hemisphere disorder.

Carotid angiography was carried out by percutaneous puncture of the common carotid artery well below the carotid bifurcation in the neck. Five films were taken in both anteroposterior and lateral projections ; an additional non-screen film was placed between the patient's neck and the lateral cassette box in order to visualize the carotid bifurcation. By means of an electronic timer the interval between exposures may be varied to provide visualization of the cerebral circulation from early arterial to late venous phases. In the last two years special attention was paid to obtaining good filling of the venous system, including oblique views of the superior longitudinal and lateral sinuses, particularly when arterial occlusion had not been demonstrated.

\section{Results}

Clinical Features.-All 31 patients had hemiplegia of varying degree and in 16 there was dysphasia as well (Table I). The onset of the stroke was abrupt in $23(74 \%)$, but in the remaining eight the definitive clinical picture developed gradually over a period ranging from half an hour to several days. Episodes of paraesthesiae in the affected limbs preceded the onset of hemiplegia in four women, and in another a convulsive episode heralded the progressive development of hemiplegia during the succeeding 24 hours. One patient suffered a convulsive episode with post-ictal paresis 10 weeks before her major stroke. Some alteration of the conscious level varying from confusion to coma was found in 19 of the patients. Headache, either preceding or accompanying the acute stroke, was a major feature in 11 cases and 10 had some visual disturbance. Paraesthesiae (seven cases) and epilepsy (six cases) were less common features. In three patients hemiplegia recurred in succeeding pregnancies, a phenomenon discussed by Sinclair (1902). One patient had developed a left hemiplegia with partial recovery in one pregnancy and in the next experienced a dense left hemiplegia; another had an episode of paraesthesia in the left hand during a previous pregnancy, and this recurred and progressed to hemiplegia in the next. The third patient had a left hemiparesis in each of three successive pregnancies, and this in the absence of any arterial or venous abnormality in the angiogram that was done on the third occasion.

Predisposing Factors.-There .were possible predisposing factors in 11 patients. Pre-eclamptic toxaemia with fluctuating hypertension was noted in five cases. In four others there was reason to believe that the onset of cerebral symptoms was 
Table I.-Clinical Features of 31 Patients with Cerebral Strokes in Pregnancy or the Puerperium

\begin{tabular}{|c|c|c|c|c|c|c|c|c|c|}
\hline $\begin{array}{l}\text { Case } \\
\text { No. }\end{array}$ & Age & $\begin{array}{l}\text { Time of Onset } \\
\text { of Stroke }\end{array}$ & Paresis & $\begin{array}{c}\text { Depression of } \\
\text { Conscious Level }\end{array}$ & Dysphasia & $\begin{array}{c}\text { Severe } \\
\text { Headache }\end{array}$ & Epilepsy & Angiography & Comment \\
\hline 1 & 24 & $\mathrm{~T}-1$ & + & - & + & - & - & ICA occlusion & $\begin{array}{l}\text { Dicd } 8 \text { months later from } \\
\text { occlasion of other ICA }\end{array}$ \\
\hline$\frac{2}{3}$ & $\begin{array}{l}27 \\
31\end{array}$ & $\begin{array}{l}\mathrm{T} \cdot 2 \\
\mathrm{~T} \cdot 2\end{array}$ & + & $\overline{-}$ & $\overline{+}$ & $\stackrel{+}{-}$ & $\overline{-}$ & $\begin{array}{l}\text { MCA occlusion } \\
\text { Terminal inch of } \\
\text { sup. long. sinus } \\
\text { not shown }\end{array}$ & \\
\hline 4 & 37 & $T-2$ & + & + & + & - & - & No occlusive lesion & \\
\hline $\begin{array}{l}3 \\
6\end{array}$ & $\begin{array}{l}33 \\
27\end{array}$ & $\begin{array}{l}\mathrm{T}-2 \\
\mathrm{~T}-2\end{array}$ & $\stackrel{+}{+}$ & $\overline{+}$ & $\overline{-}$ & $\bar{z}$ & $\overline{+}$ & MCA occlusion & $\begin{array}{l}\text { Paraesthesia in T-1 } \\
\text { Died. Multiple brain infarcts } \\
\text { and cardiomyopathy }\end{array}$ \\
\hline $\begin{array}{l}7 \\
8\end{array}$ & $\begin{array}{l}23 \\
25\end{array}$ & $\begin{array}{l}T-2 \\
T-3\end{array}$ & + & $\bar{t}$ & $\overline{+}$ & $\overline{-}$ & \pm & $\begin{array}{l}\text { No occlusive lesion } \\
\text { MCA occlusion }\end{array}$ & \\
\hline 9 & 22 & $\mathbf{T}-3$ & + & - & + & - & - & MCA occlusion & $\begin{array}{l}\text { Developed epilepsy } 18 \text { months } \\
\text { later }\end{array}$ \\
\hline $\begin{array}{l}10 \\
11\end{array}$ & $\begin{array}{l}36 \\
30\end{array}$ & $\begin{array}{l}\mathrm{T}-3 \\
\mathrm{~T}-3\end{array}$ & + & \pm & $\bar{t}$ & \pm & $\overline{-}$ & $\begin{array}{l}\text { MCA occlusion } \\
\text { No occlusive lesion }\end{array}$ & Previous epilepsy \\
\hline 12 & 29 & $T-3$ & + & + & - & - & - & MCA occlusion & $\begin{array}{l}\text { Developed epilepsy } 5 \text { months } \\
\text { later }\end{array}$ \\
\hline 13 & 22 & $T-3$ & + & + & - & - & + & No occlusive lesion & $\begin{array}{l}\text { Died. Multiple brain infarcts } \\
\text { and cardiomyopathy }\end{array}$ \\
\hline $\begin{array}{l}14 \\
15 \\
16\end{array}$ & $\begin{array}{l}23 \\
32 \\
31\end{array}$ & $\begin{array}{l}\mathrm{T}-3 \\
\mathrm{~T}-3 \\
\mathrm{~T}-3\end{array}$ & $\begin{array}{l}+ \\
+ \\
+\end{array}$ & $\bar{z}$ & $\begin{array}{l}+ \\
+ \\
+\end{array}$ & $\bar{z}$ & \pm & $\begin{array}{l}\text { MCA occlusion } \\
\text { No occlusive lesion } \\
\text { No occlusive lesion }\end{array}$ & \\
\hline $\begin{array}{l}16 \\
17\end{array}$ & $\begin{array}{l}31 \\
23\end{array}$ & $\begin{array}{l}\text { P-3 } \\
\text { Puerperium- } \\
\text { day } 11\end{array}$ & $\stackrel{+}{+}$ & $\bar{t}$ & \pm & $\overline{+}$ & $\bar{z}$ & No occlusive lesion & $\begin{array}{l}\text { Hemisphere asymmetry } \\
\text { Died. Hemisphere infanct } \\
\text { and occlusion of ICA }\end{array}$ \\
\hline 18 & 32 & $\begin{array}{l}\text { Paerperium- } \\
\text { day } 3\end{array}$ & + & + & - & + & - & $\begin{array}{l}\text { Slow filling of } \\
\text { MCA; shift }\end{array}$ & $\begin{array}{l}\text { Died. Deep pale infarct. } \\
\text { Thrombosis of small cor- } \\
\text { tical vein }\end{array}$ \\
\hline 19 & 29 & $\begin{array}{l}\text { Puerperium- } \\
\text { day } 16\end{array}$ & + & + & + & + & + & Narrowing of $\mathrm{MCA}$ & \\
\hline 20 & 23 & $\begin{array}{l}\text { Puerperium- } \\
\text { day } 2\end{array}$ & + & - & + & - & - & ICA occlusion & \\
\hline 21 & 31 & $\begin{array}{l}\text { Puerperium- } \\
\text { day } 7\end{array}$ & + & + & + & - & - & MCA occlusion & $\begin{array}{l}\text { Stroke proceded by beha- } \\
\text { vioural disorder. Caesar } \\
\text { ean section }\end{array}$ \\
\hline 22 & 31 & $\begin{array}{l}\text { Puerperium- } \\
\text { day } 5\end{array}$ & + & + & - & - & - & MCA occlusion & $\begin{array}{l}\text { Abortion. Puerperal } \\
\text { septicaemia }\end{array}$ \\
\hline 23 & 22 & $\begin{array}{l}\text { Puerperium- } \\
\text { day } 1\end{array}$ & + & - & + & - & - & MCA occlusion & \\
\hline 24 & 23 & $\begin{array}{l}\text { Puerperium- } \\
\text { day } 11\end{array}$ & + & + & - & + & - & $\begin{array}{l}\text { Notching of } 1 \\
\text { superior parietal }\end{array}$ & \\
\hline 25 & 33 & $\begin{array}{l}\text { Puerperium- } \\
\text { day } 6\end{array}$ & + & + & + & + & + & No occlusive lesion & \\
\hline 26 & 30 & $\begin{array}{l}\text { Puerperium- } \\
\text { day } 14\end{array}$ & + & + & + & + & - & MCA occlusion & Died. Cerebral infarct \\
\hline 27 & 35 & $\begin{array}{l}\text { Puerperium- } \\
\text { day } 12\end{array}$ & + & + & + & - & - & ICA occlusion & Died. Cerebral infarct \\
\hline 28 & 36 & $\begin{array}{l}\text { Puerperium- } \\
\text { day } 3\end{array}$ & + & + & - & - & - & - & Died. Cerebral infarct \\
\hline 29 & 23 & $\begin{array}{l}\text { Puerperium- } \\
\text { day } 7\end{array}$ & + & + & - & + & - & - & $\begin{array}{l}\text { Died. ICA occlusion. } \\
\text { Caesarean section }\end{array}$ \\
\hline 30 & 33 & $\begin{array}{l}\text { Puerperium- } \\
\text { day } 5\end{array}$ & + & + & - & + & - & ICA occlusion & Caesarean section at term \\
\hline 31 & 37 & $\begin{array}{l}\text { Puerperium- } \\
\text { day } 2\end{array}$ & + & + & -- & + & - & No occlusive lesion & Abortion at 28th week \\
\hline
\end{tabular}

T- $1=$ First trimester. $T-2=$ Second trimester. T-3 $=$ Third trimester. ICA - Internal carotid artery. MCA $=$ Middle cerebral artery, trunk or major branch. Puerperium $=$ All cases occurring after delivery.

related to an acute hypotensive episode-two from blood loss and two from cardiomyopathy. Another patient had hypertension without toxaemia and the last developed puerperal septicaemia following spontaneous abortion. Martin (1941) considered the presence of phlebothrombosis in the lower limbs and pelvis to be of significance in the pathogenesis of cerebral strokes from venous thrombosis associated with childbirth, but of our two cases with phlebothrombosis in the lower limbs one had occlusion of the middle cerebral artery and the other a deep-seated ischaemic infarct without major vessel occlusion.

Incidence of Strokes in Pregnancy.-During the period in which our 31 cases were investigated there were approximately 600,000 births in the Western Region of Scotland, giving an incidence of major ischaemic carotid territory stroke of 1 case per 20,000 births. The incidence of cerebral venous thrombosis in association with childbirth has been variously assessed, from 1 in 1,666 pregnancies (Goldman, Eckerling, and Gans, 1964) to 1 in 10,000 (Huggenberg and Kesselring, 1958). Of the 65 women aged $15-45$ years investigated for carotid stroke during the 10-year period 1956-65 no fewer than $23(35 \%)$ were pregnant or puerperal at the time of their stroke. This is more than three times the pregnancy rate of women in this age group in the Western Region of Scotland, which is about 10\% (Western Regional Hospital Board Statistics, 1965).

Age.-Non-haemorrhagic strokes in association with pregnancy tend to occur at a younger age than in non-pregnant women of child-bearing years. Reports from other sources show that most strokes in association with pregnancy occur below the age of 35 years, but this probably reflects no more

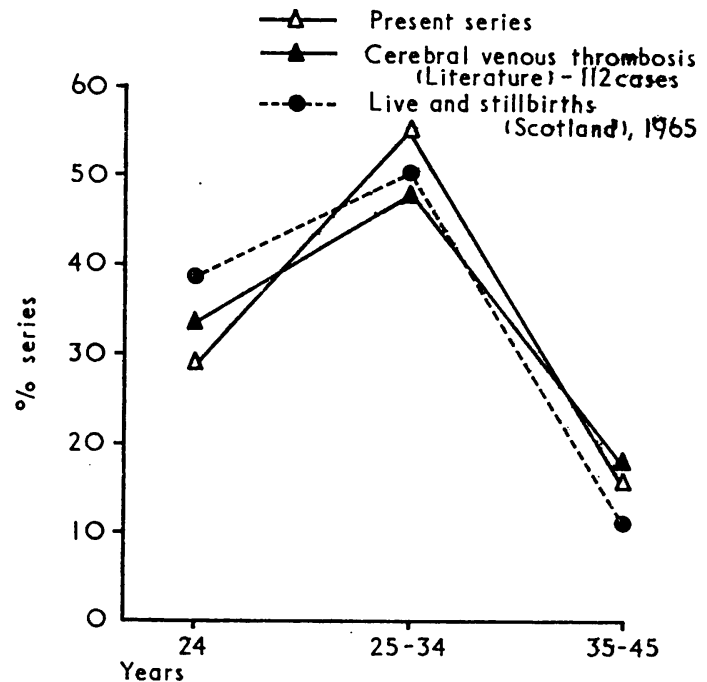

FIG 1.-Age-specific distribution of strokes associated with childbirth compared with age distribution of pregnant women (Scotland). Sources of information: Annual Report of the Registrar General for Scotland (1965); Institute of Neurological Sciences, Glasgow; B Bckel and Baran (1952); Boshes and McBeath (1954); Burt, Donnelly, and whitener (1951); Cairns and Melton (1942); Carroll, Leak, and Lee (1966); Davidson (1945); Fishman, Cowen, and Silbermann (1957); Hunt (1917); Hyland (1950); Joseph (1942); Kendall (1948); King ; (1950); Koek and Schreuder (1951); Krayenbühl (1954); Lemmi and Little (1960); Lorincz and Moore (1962); MaNairn (1948); Martin and (1960); Lorincz and Moore (1962); MaNairn (1948); Martin and (1965); Sinclair (1902); Stansfield (1942); Stevens (1954, 1958); Stevens and Ammerman (1959). Symonds (1940). 
than the age-specific distribution of pregnancy in the population (Fig. 1).

Time of Onset.-Only one stroke developed in the first trimester. As many cases occurred after delivery as in the whole of the last six months of pregnancy; about half of the puerperal strokes occurred within a week of delivery and the remainder between the eleventh and sixteenth days. The majority of reported non-haemorrhagic strokes in association with childbirth have occurred during the puerperium.

\section{Investigation}

Carotid angiography was carried out in 27 of the patients and in the remainder the diagnosis was established at necropsy; 17 cases ( $55 \%$ ) were found to have occlusion of a major cerebral artery, most commonly (11 cases) the middle cerebral artery (Table II). Complete occlusion of the internal carotid artery was demonstrated in six patients, in all but one at the bifurcation in the neck. In 14 women no occlusive arterial lesion could be demonstrated; in two of these necropsy showed infarction of the brain in a pattern consistent with acute perfusion failure in association with cardiomyopathy, and one of these cases has been reported in detail elsewhere (Connor and Adams, 1966). Post-mortem examination in one patient showed infarction of the basal ganglia and adjoining internal capsule in relation to a large, calcified, unruptured aneurysm of the internal carotid artery, and in another there was narrowing of the middle cerebral artery. In only two cases did the phlebogram suggest any deficiency of the venous system: in one there was notching of a superior cerebral vein close to its point of entry into the superior longitudinal sinus, and in the other the terminal inch of the superior longitudinal sinus was not demonstrated.

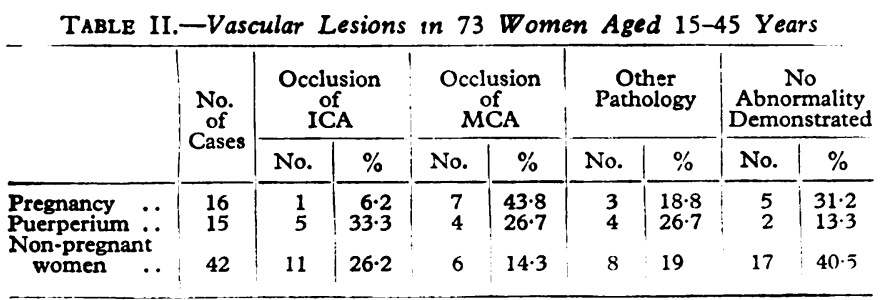

In only one of the nine patients in whom necropsy was performed was evidence of cortical venous thrombosis found; this was associated with a pale infarct of the insula and central part of the precentral gyrus. A small haemorrhagic area on the superficial aspect of the precentral gyrus was related to thrombosis of a small cortical vein, but it was not felt that the pale, deeply situated infarct resulted from this cause.

Thus in $71 \%$ of the cases there was evidence of ischaemia of the cerebral hemispheres which could be related to a deficient arterial supply rather than to thrombosis of the intracranial venous system.

\section{Mortality}

Eight of the 31 patients ( $26 \%$ ) died as a result of their acute stroke, and another had a further stroke from which she died several months later. We have already drawn attention to the much higher mortality rate of ischaemic carotid territory strokes in pregnant and puerperal women than in men $(13.6 \%)$ or in non-pregnant women $(9.5 \%)$ of the same age group (Jennett and Cross, 1967). Post-mortem reports are available on all of the nine patients who died. Raised intracranial pressure with tentorial herniation accounted for five of the deaths, and this was due to massive swelling associated with the infarct.

\section{Discussion}

The occurrence of non-haemorrhagic cerebral stroke in association with pregnancy and the puerperium is a well-recognized, though fortunately infrequent, syndrome, reports of which date for more than a century and a half. Early accounts described the necropsy finding of thrombosis of cerebral veins and/or venous sinuses, and interest in this condition was renewed by the papers of Symonds (1940), Martin (1941), Martin and Sheehan (1941), and Stansfield (1942), which described a total of 11 cases of a similar clinical pattern, in four of which a diagnosis of intracranial venous occlusion was confirmed at operation or necropsy. Martin invoked Batson's work on the vertebral venous plexus as providing a possible anatomical pathway for the propagation of thrombi from the pelvic veins to the intracranial venous complex. However, Kendall (1948) argued cogently against this hypothesis, and, in view of the difficulty experienced by Beck (1948) in trying to produce thrombosis of the dural sinuses experimentally, it seems unlikely that intracranial venous thrombosis would readily develop secondary to thrombosis of the pelvic veins. Also, of 34 cases of cerebral venous thrombosis confirmed at post-mortem examination, only seven had evidence of thrombosis of the pelvic or lower limb veins (Carroll, Leak, and Lee, 1966).

Whatever its pathogenesis, primary non-septic intracranial venous thrombosis has become accepted widely as the most common cause of strokes associated with pregnancy and the puerperium, and Carroll et al. were able to collect from the literature 177 cases of non-haemorrhagic cerebral stroke in association with childbirth, to which they added four of their own, all ascribed to cerebral venous thrombosis. However, in only 34 of these 181 cases had the diagnosis been confirmed at post-mortem examination: no mention is made of confirmation by other means such as angiography, but it would appear that in the majority of cases the nature of the pathological lesion was assumed rather than proved.

Krayenbühl (1954) stressed the importance of cerebral angiography as a means of excluding other lesions in patients suspected of having cerebral venous thrombosis. He considered, moreover, that a deficiency in the venous phase of the angiogram could be diagnostic of primary cortical vein occlusion. Despite his advocacy of angiography this mode of investigation has been applied in only a minority of cases of this type. Thus angiography was mentioned in only 10 out of 77 cases reported in the last two decades, and the clinical diagnosis was verified by this means or by necropsy in only 16 of these 77 cases (data from McNairn (1948), Kendall (1948), Hyland (1950), King (1950), Burt et al. (1951), Koek and Schreuder (1951), Bickel and Baran (1952), Stevens (1954, 1958), Stevens and Ammerman (1959), Krayenbühl (1954), Fishman et al. (1957), Lemmi and Little (1960), Fisher and Rollas (1960), Prakash and Singh (1960), Lorincz and Moore (1962), Boshes and McBeath (1954), Richards (1965), Carroll et al. (1966), and Kalbag and Woolf (1967)).

It might be argued that in those patients in our series in whom neither arterial occlusion nor other ischaemic lesion was demonstrated there may well have been primary involvement of the cerebral veins. However, critical review of the angiograms has not shown any deficiency of the intracranial venous pattern apart from the two cases previously mentioned. In view of Scarff's (1944) experience with excising Pachionian granulations and ligating the draining veins (for epilepsy) in 23 patients, with no resulting neurological deficit in half of his cases and only transient sequelae in the rest, it is difficult to accept that the venous abnormalities shown in our two cases were responsible for the dramatic clinical picture presented by these patients.

With the lowest reported incidence of cerebral venous thrombosis associated with pregnancy ( 1 in 10,000) some 60 cases of this condition with 20 deaths would have been expected in this region during the years 1956-67. The remarkable feature of our experience was not only that we found so many arterial lesions but that we found cortical venous occlusion on angiography or at post-mortem examination in only one case. The absence of this condition from the files on maternal 
mortality in the records of the City of Glasgow, despite an overall mortality of some $33 \%$ for cerebral venous thrombosis in pregnancy and the puerperium in the literature (Carroll et al., 1966), suggests that this entity is of rare occurrence when strict diagnostic criteria are applied. Moreover, we have previously published evidence which indicates that in British and United States statistics hemiplegia in association with childbearing is not usually indexed under the International Classification of Diseases rubrics for arterial occlusion or cerebral infarction (Jennett and Cross, 1967). The Glasgow series of women aged 15-45 years conforms to other sources only when pregnant women are excluded (Fig. 2).

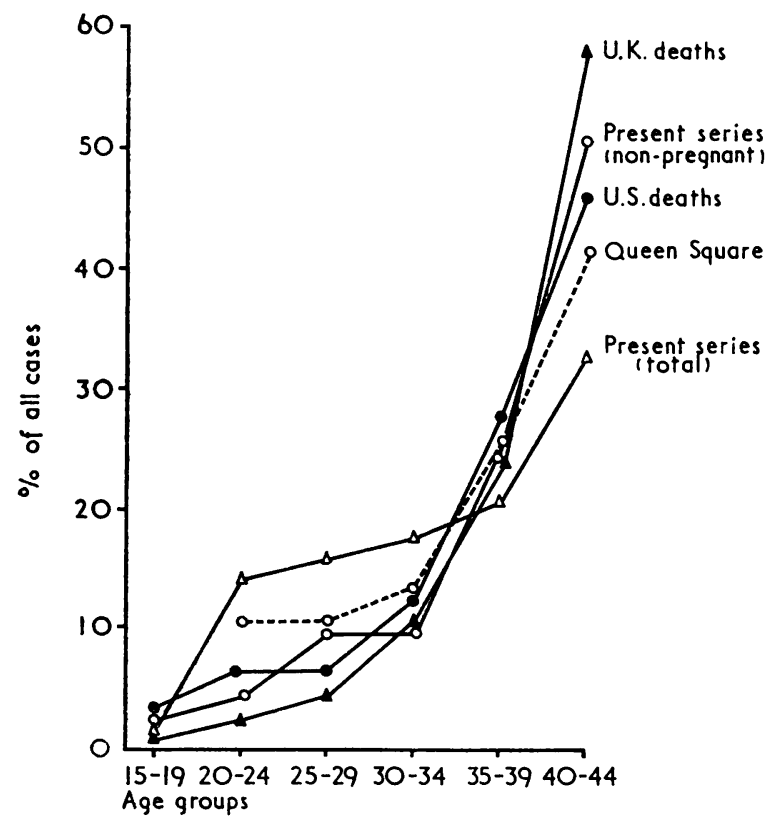

Fig. 2.-Age-specific prevalence of ischaemic stroke in women 15-45 years old. Sources of information: U.K. deaths, Registrar General, 19541963 ; U.S. deaths, Food and Drug Administration (1966) ; Arterial occlusions at National Hospital, Queen Square, London (Illis et al., 1965); Present series, Institute of Neurological Sciences, Glasgow (reproduced by permission of the Editor of the Lancet).

It is interesting that Martin (1958) suggested that strokes in the antepartum period were similar to those in non-pregnant women and were usually arterial in origin: he proposed thrombosis of the cerebral veins as the aetiological factor only for puerperal strokes. Our experience provides no support for this distinction. Indeed, the incidence of arterial occlusion and other ischaemic lesions in the cases occurring after delivery exceeded that in the antepartum group (Table I). Occlusion of the internal carotid artery occurred more often in the postpartum group than in the patients with strokes during the course of pregnancy. On the other hand, the middle cerebral artery was more often involved in the cases occurring before delivery.

One factor which may contribute to the inadequate investigation of this group of patients is the failure to realize that arterial lesions in women of this age group are by no means unusual. Thus Lorincz and Moore (1962) wrote: "arterial thrombosis in women of child-bearing age is very improbable in the absence of severe hypertension or diabetes mellitus." However, Johnson and Walker (1951) found in 107 cases of spontaneous occlusion of the common and internal carotid arteries that half of the 20 women were under 45 years of age. Illis, Kocen, McDonald, and Mondkar (1965) and Jennett and Cross (1967) both found $12 \%$ of their large series of cases of ischaemic cerebrovascular disease were women of child-bearing years. Humphrey and Newton (1960) found seven women in a series of 17 patients under the age of 40 with complete occlusion of the internal carotid artery; moreover, only one of these cases showed any evidence of hypertension, diabetes, or atherosclerotic involvement of major arteries. Of the 10 women in their series seven were less than 40 years of age. Adams and Graham (1967) reported eight cases of women under the age of 45 with fatal cerebral infarction as a result of arterial occlusion in the absence of atheromatous stenosis or embolism. Three of these cases had developed their arterial occlusions in the puerperium and are included in the present series.

It is a matter of some concern that patients with cerebrovascular disease of this nature should have pathological labels assigned to them on the basis of clinical features alone. Kendall (1948) claimed that the triad of convulsions, headache, and varying degrees of paresis in a puerperal woman was likely to be the result of thrombosis of an intracranial sinus or vein. In fact, comparison of the clinical features supposedly associated with cerebral venous thrombosis shows that there is considerable variation in the clinical patterns reported in the literature (Table III).

TABLE III.-Comparison of Clinical Features in Some Reported Series of Strokes in Pregnant or Puerperal Women

\begin{tabular}{|c|c|c|c|c|c|}
\hline Feature & $\begin{array}{c}\text { Present } \\
\text { Series } \\
(31 \\
\text { Cases })\end{array}$ & $\begin{array}{c}\text { Goldman } \\
\text { et al. } \\
(1964) \\
\text { (15 Cases) }\end{array}$ & $\begin{array}{c}\text { Fruhinsholz } \\
\text { and Cornil } \\
(1929) \\
\text { (16 Cases) }\end{array}$ & $\begin{array}{c}\text { Prakash } \\
\text { and Singh } \\
(1960) \\
\text { (21 Cases) }\end{array}$ & $\begin{array}{c}\text { Carroll } \\
\text { et al. } \\
\text { (1966) } \\
\text { (181 Cases) }\end{array}$ \\
\hline $\begin{array}{l}\text { Paresis } \\
\text { Depression of con- }\end{array}$ & $100 \%$ & $93 \cdot 3 \%$ & $81 \cdot 3 \%$ & $100 \%$ & $45 \%$ \\
\hline $\begin{array}{ll}\text { scious level } & \ldots \\
\text { Dysphasia } & \ldots \\
\text { Headache } & \ldots \\
\text { Epilepsy } & \ldots \\
\text { Vomiting .. } & \ldots \\
\text { Visual disturbance } \\
\text { Paraesthesia }\end{array}$ & $\begin{array}{l}61.3 \% \\
51.6 \% \\
35.5 \% \\
19.3 \% \\
22.6 \% \\
32.3 \% \\
16.1 \%\end{array}$ & $\begin{array}{l}80 \% \\
46.7 \% \\
100 \% \\
100 \% \\
100 \% \\
=\end{array}$ & $\begin{array}{r}25 \% \\
75 \% \\
25 \% \\
=\end{array}$ & $\begin{array}{l}28 \cdot 6 \% \\
23 \cdot 8 \% \\
57 \cdot 1 \% \\
38 \cdot 1 \% \\
= \\
=\end{array}$ & $\begin{array}{l}17 \% \\
24 \% \\
34 \% \\
30 \% \\
10 \% \\
6 \% \\
10 \%\end{array}$ \\
\hline
\end{tabular}

The unreliability of clinical features alone in distinguishing various types of cerebral vascular disease has been demonstrated convincingly by Bull, Marshall, and Shaw (1960). Accurate diagnosis is not merely a matter of "academic" interest : five of our patients had occlusion of the internal carotid artery in the neck, where early disobliterative surgery might have been possible.

We wish to thank the clinical consultants of the Institute of Neurological Sciences, Glasgow, for allowing us to report patients under their care, and those pathologists in other hospitals who kindly provided information on the necropsies on patients previously investigated in the Institute. We are indebted to Dr. Margaret C. Barron, of the Health and Welfare Department, Glasgow, for access to information on maternal mortality in Glasgow.

This investigation forms part of a study on cerebrovascular disease supported by Scottish Hospital Endowments Research Trust.

\section{REFBRENCES}

Adams, J. H., and Graham. D. I. (1967). 7. Neurol. Neurosurg. Psychiar.,

Beck, D. K. (1944). Proc. roy. Soc. Med., 37, 388.

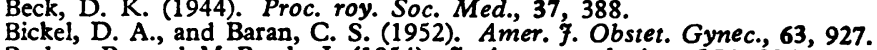
Boshes, B., and M=Beath, J. (1954). भ. Amer. med. Ass., 154, 385 .

Bull, J. W. D., Marshall, J., and Shaw, D. A. (1960). Lancet, $1,562$.

Burt, R. L., Donnelly, J., F., and Whitener, D. L. (1951). Amer. F. Obstet. Gynec., 62, 639

Cairns, D. R., and Melton, G. (1942). Brit. med. 7., 1, 439.

Carroil, J. D., Leak, D., and Lee. H. A. (1966). Quart. F. Med., 35, 347.

Connor, R. C. R., and Adams, J. H. (1966). \%. clin. Path., 19, 244.

Davidson, W. G. (1945). N.Z. med. $7.44,101$

Fisher, R. G., and Rollas, Z. (1960). 7 . Amer. med. Ass, 174, 155. Fisher, R. G., and Rollas, Z. (1960). F. Amer. med. Ass, 174, 155.
Fishman. R. A., Cowen, D., and Silbermann, M. (1957). Neurology
(Minneap.), 7, 217.

Fruhinsholz, A., and Cornil, L. (1929). Presse méd., 37, 617.

Goldman, J. A., Eckerling, B., and Gans, B. (1964). J. Obstet. Gynaec. Brit. Cwlth, 71, 791 .

Huggenberg, H. R., and Kesselring, F. (1958). Gynaecologia (Basel), 146, 312. Quoted by Goldman et al. (1964).

Humphrey, J. G., and Newton, T. H. (1960). Brain, 83, 565.

Hunt, J. R. (1917). Bull. Lying-in-Hosp. N.Y., 11, 73.

Hyland, H. H. (1950). Y. Amer. med. Ass., 142, 707. 
Illis, L., Kocen, R. S., McDonald, W. I., and Mondkar, V. P. (1965). Brit. med. F., $2,1164$.

Jennett, W. B., and Cross, J. N. (1967). Lancet, 1, 1019.

Johnson, H. C., and Walker, A. E. (1951). F. Neurosurg., 8, 631.

Joseph, J. (1942) Brit. med. Ұ., 1, 438.

Kalbag, R. M., and Woolf, A. L. (1967). Cerebral Venous Thrombosis, Pp. 176-178. London.

Kendali, D. (1948). Brain, 71, 386.

King, A. B. (1950). Arch. Neurol. Psychiat. (Chic.), 63, 471, 611.

Koek, H. C., and Schreuder, J. Th. R. (1951). Acta psychiat. scand., 26, 353.

Krayenbühl, H. (1954). Schweiz. Arch. Neurol. Psychiat., 74, 261.

Lemmi, H., and Little, S. C. (1960). Arch. Neurol. (Chic.), 3, 252.

Lorincz, A. B., and Moore, R. Y. (1962). Amer. F. Obstet. Gynec., 83, 311 .
McNairn, J. (1948). 7. Obstet. Gynaec. Brit. Emp., 55, 630.

Martin, J. P. (1941). Brit. med. I., 2, 537.

Martin, J. P. (1944). Proc. roy. Soc. Med., 37, 383.

Martin, J. P. (1958). Brit. med. F., 2, 315 .

Martin, J. P., and Sheehan, H. L." (1941). Brit. med. 9, 1, 349.

Prakash, C., and Singh, S. (1960). 7. Ass. Phycns India, 35, 363.

Richaras, D. J. (1965). Postgrad. med. . ., 41, 702.

Scarf, J. E. (1944). Proc. roy. Soc. Med., 37, 389.

Sinclair, M. A. Mcl. (1902). Lancet, 2, 204.

Stansfield, F. R. (1942). Brit. med. 7., 1, 436.

Stevens, H. (1954). Neurology (Minneap.), 4, 723.
Stevens, H. (1958). Ann. intern. Med., 49, 1022.

Stevens, H., and Ammerman, H. H. (1959). Amer. F. Obsset. Gynec., 78, 104.

Symonds, C. P. (1940). Brit. med. F., 2, 348.

\title{
Effects of Low-dose Oral Contraceptives on Blood Coagulation*
}

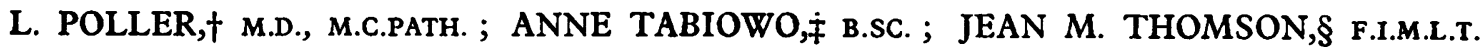

Brit. med. F., 1968, 3, 218-219

\begin{abstract}
Qummary : A study has been performed on the effect of Norinyl-1 and Ortho-Novin, two low-dose oral contraceptives, on blood-clotting factors. Ortho-Novin contains twice the amount of hormone as Norinyl-1. It was therefore possible to observe whether any changes detected were related to the dose of oestrogen-progestin combination. The women were tested in parallel with matched normal female controls and a group in the third trimester of pregnancy. Significant rises in factor VII and X levels were found with both low-dose preparations from the third month onwards. There was no difference between patients on Norinyl-1 and Ortho-Novin, and hence the clotting changes do not appear to be dose-dependent. The long-term effects on clotting factors of these lowdose oral contraceptive preparations remain to be investigated.
\end{abstract}

\section{Introduction}

In previous studies we found an increase in plasma clotting factors VII and X in women taking oral contraceptive preparations, and this rise became statistically significant from the third month onwards (Thomson and Poller, 1965 ; Poller and Thomson, 1966). The present investigations were designed to determine whether this effect depended on the dose of antiovulatory agent, and whether the time relationship of the consequent changes would be affected by the hormonal dose. Women volunteers were given two different preparations of relatively low hormonal content, one of which-Ortho-Novincontained twice the dose (norethisterone $2 \mathrm{mg}$., mestranol $0.1 \mathrm{mg}$.) of the other-Norinyl-1. Parallel studies were performed on women controls and a group of patients in their third trimester of pregnancy.

\section{Method of Study}

The women of this investigation volunteered to co-operate in the study following an appeal for participants in a trial of

\footnotetext{
* This work was undertaken with the financial assistance of a grant for thrombosis research from Manchester Regional Hospital Board and a
grant from the Council for the Investigation of Fertility Control. grant from the Council for the Investigation of Fertility Control.
Syntex Pharmaceuticals Ltd. kindly provided the low-dose hormone Syntex Pharmaceuticals Ltd. kindly provided the low-dos
preparation used in this study and patient data sheets. t Consultant Haematologist.

$\ddagger$ Research Technician.

5 Chief Research Technician.

Withington Hospital, Manchester 20
}

low-dose oral contraceptives. Their clotting factors were studied before starting the "pill" preparations. They were tested at intervals of six weeks for three months, and then at intervals of three months for nine months. This report deals with the results to the nine-month stage.

The women participating consisted of 31 patients on OrthoNovin who had not previously taken oral contraceptives and 60 women on Norinyl-1. Of the latter group 34 had not previously taken oral contraceptives and 26 had been taking some other preparation within the preceding six months. An antenatal group consisting of 43 ambulatory patients in the third trimester of pregnancy attending Withington Maternity Hospital were studied as a control group. The normal group consisted of equal numbers of matched normal females tested at the same time as the oral contraceptive and antenatal patients.

To eliminate possible variables that occur in assays owing to alteration in reagents and other factors from day to day, each of the oral contraceptive groups was compared statistically with the simultaneous parallel group of normals and the antenatal patients.

Technique.-The method for prothrombin activity (Quick's test), cephalin time, and factor VII and factor X assays were as described previonsly. The method for the kaolin-activated cephalin time was the cephalin time method as described by Hjort et al. (1955), modified by the addition of kaolin.

\section{Results}

Of the original 91 patients 75 were still in the trial after their sixth monthly course and 56 patients were left after the ninth course. Of the three oral contraceptive groups 18 remained on Ortho-Novin and 21 and 17 respectively in the two Norinyl-1 groups after nine months.

When the results of the patients taking oral contraceptives were compared as groups with their parallel normal controls as well as with the parallel antenatal groups there was no significant difference in the prothrombin time results between any of the groups. Analysis of the cephalin times showed a significant shortening $(P=0.05)$ with the unmodified test and with the kaolin-activated test from the sixth month onwards, but only when all the oral contraceptive patients were considered as a combined group. 